\title{
Ecosystem services-current challenges and opportunities for ecological research
}

\author{
Klaus Birkhofer ${ }^{1 * \dagger}$, Eva Diehl ${ }^{2 \dagger}$, Jesper Andersson ${ }^{1}$, Johan Ekroos $^{3}$, Andrea Früh-Müller ${ }^{2}$, \\ Franziska Machnikowski ${ }^{2}$, Viktoria L. Mader ${ }^{2}$, Lovisa Nilsson $^{3}$, Keiko Sasaki ${ }^{2}$, Maj Rundlöf ${ }^{1}$, \\ Volkmar Wolters ${ }^{2}$ and Henrik G. Smith ${ }^{1,3}$
}

${ }^{1}$ Biodiversity Unit, Department of Biology, Lund University, Lund, Sweden

${ }^{2}$ Department of Animal Ecology, Justus Liebig University, Gießen, Germany

${ }^{3}$ Centre for Environmental and Climate Research, Lund University, Lund, Sweden

\section{Edited by:}

Johann G. Zaller, University of Natural Resources and Life Sciences Vienna, Austria

\section{Reviewed by:}

Quang Bao Le, ETH Zurich, Switzerland

Visa Nuutinen, MTT Agrifood

Research Finland, Finland

\section{*Correspondence:}

Klaus Birkhofer, Department of Biology, Biodiversity and

Conservation Science, Lund

University, Sölvegatan 37,

22362 Lund, Sweden

e-mail: klaus.birkhofer@biol.lu.se

${ }^{\dagger}$ These authors have contributed equally to this work.
The concept of ecosystem services was originally developed to illustrate the benefits that natural ecosystems generate for society and to raise awareness for biodiversity and ecosystem conservation. In this article we identify major challenges and opportunities for ecologists involved in empirical or modeling ecosystem service research. The first challenge arises from the fact that the ecosystem service concept has not been generated in the context of managed systems. Ecologists need to identify the effect of anthropogenic interventions in order to propose practices to benefit service-providing organisms and associated services. The second challenge arises from the need to evaluate relationships between indicators of ecosystem services that are collected in ecological studies while accounting for uncertainties of ecological processes that underlie these services. We suggest basing the assessment of ecosystem services on the utilization of sets of indicators that cover aspects of service-providing units, ecosystem management and landscape modification. The third challenge arises from the limited understanding of the nature of relationships between services and a lack of a general statistical framework to address these links. To manage ecosystem service provisioning, ecologists need to establish whether services respond to a shared driver or if services are directly linked to each other. Finally, studies relating biodiversity to ecosystem services often focus on services at small spatial or short temporal scales, but research on the protection of services is often directed toward services providing benefits at large spatial scales. Ecological research needs to address a range of spatial and temporal scales to provide a multifaceted understanding of how nature promotes human well-being. Addressing these challenges in the future offers a unique opportunity for ecologists to act as promoters for the understanding about how to conserve benefits gained from nature.

Keywords: anthropogenic interventions, biodiversity conservation, ecosystem services, multiple services, serviceproviding units, spatial scale, temporal scale, trade-offs

\section{INTRODUCTION}

The concepts of nature's services (Westman, 1977) or ecosystem services (Ehrlich and Ehrlich, 1981) were originally developed to draw attention to the benefits that ecosystems generate for society and to raise awareness for biodiversity conservation. Since ecosystem services by definition depend on ecological functions, revealing their value should in theory entice managers and policy makers to safeguard those functions. In an early attempt, Costanza et al. (1997) estimated the monetary value of 17 ecosystem services to range from US\$16-54 trillion per year, initiating a wave of research on how to value ecosystem services (De Groot et al., 2002; Engel et al., 2008; TEEB, 2010). Although the valuation of ecosystem services is complex and controversial, the concept has had major consequences for the development of environmental research and policies in the last decades. The Millennium Ecosystem Assessment, in a global assessment of the status and drivers of past and expected future changes in the delivery of ecosystem services, demonstrated the urgent need for research in this field (Millennium Ecosystem Assessment, 2005).

There is a range of definitions for ecosystem services based on diverging views on how they are generated and linked to human well-being (see Vihervaara et al., 2010 and Seppelt et al., 2011 for reviews) leading to alternative classification schemes (De Groot, 2006; Boyd and Banzhaf, 2007; Zhang et al., 2007; Fisher et al., 2009; De Groot et al., 2010; Haines-Young and Potschin, 2010). The term "ecosystem services" was originally intended to highlight both direct and indirect benefits humans obtained from nature (Daily, 1997). The risk of double counting in economic valuation later motivated some researchers to advocate that the term should be restricted to the final benefits obtained by humans (Boyd and Banzhaf, 2007). De Groot et al. (2002), for example, integrated information from ecology and economics to 
propose a comprehensive concept that described, classified, and valued ecosystem functions and the resulting final goods and services provided by natural and semi-natural systems. However, the Millennium Ecosystem Assessment (2005) explicitly considered supporting ecosystem services as ecosystem functions underlying other ecosystem services, i.e., provisioning services (products obtained from ecosystems, e.g., food, fiber, and water), regulating services (benefits obtained from regulation of ecosystem processes, e.g., climate regulation, flood regulation) and cultural services (non-material benefits people obtain from ecosystems, e.g., recreational, aesthetic and spiritual benefit). In contrast, the global initiative "The Economics of Ecosystems and Biodiversity" (TEEB, 2010) to value biodiversity, considered supporting services as ecological processes, but instead added habitat services as an additional concept.

Ecologists have an important role in ecosystem service research, because services irrespective of the definition and classification are related to organisms and their interactions with the environment (Feld et al., 2009). Hence, the focus of an ecologist is particularly at the role of biodiversity and ecosystem functions underpinning the services and goods directly appreciated by humans, i.e., the intermediate ecosystem services in the terminology of Fisher et al. (2009). It is these functions which remain invisible and risk being underprovided if research does not reveal their contribution to the final services. For example, several ecosystem services are linked to distinct groups of organisms ("service-providing units"; Luck et al., 2003). Examples include biological control of pests (performed by natural enemies) and pollination (performed by pollinating insects) which both contribute to agricultural yields, carbon sequestration (performed by soil organisms) that contributes to climate regulation, reduction of water flows (performed by vegetation) that contributes to flood control and the intrinsic value of biodiversity (Mace et al., 2012). Changes in population size or community composition of these service-providing units in response to anthropogenic activities often affect intermediate and therefore also final ecosystem services (Raffaelli and White, 2013). In fact, human impact has been identified as the main driver of changes in ecosystems and associated services (Millennium Ecosystem Assessment, 2005). Consequently, information about effects of land-use change on service-providing units and associated ecosystem services is increasingly demanded by managers and policy makers in order to promote the sustainable use and continuous provision of services (e.g., by the conference of the parties to the convention on biological diversity; CBD, 2010).

Understanding interactions between ecosystem properties and processes is a basic domain of ecology and is crucial to map and manage final ecosystem services. However, there are major challenges facing ecologists engaged in this field. First, ecosystem services are by definition determined by the interaction between ecological and social systems, because only ecosystem processes that contribute to the fulfillment of human needs are ecosystem services. This requires ecologists to work with scientists from other disciplines when trying to understand how ecosystems contribute to human welfare. Second, attempts to use the concept to quantify management consequences on ecosystem functions and resulting changes in the economic value of goods and services may oversimplify complex interactions in social-ecological systems (Norgaard, 2010). For example, monetization of nature's services may result in better management of some services, but still underestimates the value of preserving ecosystem functions for long-term sustainability (Sterner and Persson, 2008). Some services may also fail to become incorporated into an optimization framework, such as conservation of biodiversity per se, because they are not transactable (Mace et al., 2012). A fundamental understanding of the ecosystem processes responsible for ecosystem services, including the contribution of organisms to these processes, is a necessary part of ecosystem service research and involves both challenges and opportunities to ecologists (e.g., Hails and Ormerod, 2013).

\section{CHALLENGES AND OPPORTUNITIES}

By understanding the links between natural and social systems, ecosystem service research aims at developing more sustainably managed ecosystems (Daily et al., 2009). Although this framework may appear oversimplified (Braat and De Groot, 2012), and ecological-economic modeling may better represent socialecological systems (Reyers et al., 2013), it shows the inherently cross-disciplinary character of ecosystem service research. Here we focus on some selected conceptual, methodological, and statistical challenges arising in empirical ecological studies and associated modeling approaches to ecosystem service research based on our experiences as ecologists and landscape planners (Garibaldi et al., 2013; Lundin et al., 2013; Setälä et al., 2014; Ekroos et al., 2014; Früh-Müller et al., 2014). We further provide recommendations about how to deal with these challenges by highlighting opportunities for ecologists to contribute to ecosystem service research in the future. In the following sections, we discuss challenges for ecologists in ecosystem service research when dealing with anthropogenic modifications of ecosystems (challenge 1), assessment of services (challenge 2) including statistical pitfalls and issues of causality when analyzing relationships between multiple ecosystem services (challenge 3) and spatial and temporal scales at which services are provided and/or managed (challenge 4; see Table 1 for an overview of the challenges addressed).

\section{CHALLENGE 1: UNDERSTANDING ANTHROPOGENICALLY MODIFIED SYSTEMS}

Initial accounts focused on ecosystem services provided by natural systems (Westman, 1977; Daily, 1997), while ecosystem services associated to managed ecosystems have only received attention later (e.g., Tylianakis et al., 2007). Ecologists need to communicate that the concept of ecosystem services is useful to understand how management of human-modified landscapes affect both the production of goods and environmental externalities. For ecologists working in such anthropogenically modified systems (e.g., agricultural landscapes, production forest or urban areas) challenges arise in (i) the identification of human impact on service-providing units and associated ecosystem services and (ii) considering effects of landscapes surrounding land units that provide ecosystem services.

Ecosystems that are managed to produce food, fuel or fiber or local public infrastructure comprise large proportions of the 


\section{Table 1 | Selected challenges and sub-challenges discussed in this article, with opportunities for ecologists to contribute to improved recommendations regarding the management of ecosystem services.}

\begin{tabular}{|c|c|c|}
\hline Challenge & Sub-challenge & Opportunities \\
\hline $\begin{array}{l}\text { 3.1. Understanding } \\
\text { anthropogenically } \\
\text { modified systems }\end{array}$ & $\begin{array}{l}\text { (i) Identifying human impact on service-providing units } \\
\text { and ecosystem services } \\
\text { (ii) Considering matrix effects in modified landscapes }\end{array}$ & $\begin{array}{l}\text { Consideration of relationships between biodiversity and ecosystem } \\
\text { service provision and management interventions } \\
\text { Identifying effects of anthropogenic interventions on service-providing } \\
\text { units at different spatial scales }\end{array}$ \\
\hline $\begin{array}{l}\text { 3.2. Assessing } \\
\text { ecosystem services }\end{array}$ & $\begin{array}{l}\text { (i) Assessing relationships between services and } \\
\text { measures usually quantified in ecological studies } \\
\text { (ii) Accounting for dynamics and uncertainties in } \\
\text { models of service provision }\end{array}$ & $\begin{array}{l}\text { Identifying ecological measures that are reliable indicators of } \\
\text { ecosystem service provision } \\
\text { Evaluation of uncertainty, integration of evolutionary aspects and } \\
\text { human impacts into process-based models and socio-economic models }\end{array}$ \\
\hline $\begin{array}{l}\text { 3.3. Analyzing } \\
\text { relationships } \\
\text { between } \\
\text { ecosystem services }\end{array}$ & $\begin{array}{l}\text { (i) Understanding if relationships between ecosystem } \\
\text { services are indirect or direct } \\
\text { (ii) Solving issues with the visualization and statistical } \\
\text { testing of relationships between multiple services }\end{array}$ & $\begin{array}{l}\text { Performing studies that model direct and indirect effects, experimental } \\
\text { test for relationships and developing mechanistic models } \\
\text { Accounting for non-linear relationships when visualizing or analyzing } \\
\text { relationships between services }\end{array}$ \\
\hline $\begin{array}{l}\text { 3.4. Considering } \\
\text { appropriate spatial } \\
\text { and temporal scales }\end{array}$ & $\begin{array}{l}\text { (i) Up scaling from experimental plots to scales } \\
\text { relevant for management of most ecosystem services } \\
\text { (ii) Understanding temporal dynamics of service } \\
\text { provision to develop sustainable management and } \\
\text { conservation strategies }\end{array}$ & $\begin{array}{l}\text { Coupling research on mechanisms for service provision with } \\
\text { conservation-oriented research } \\
\text { Utilizing existing long-term studies and promoting the need for such } \\
\text { research projects }\end{array}$ \\
\hline
\end{tabular}

world's terrestrial surface, e.g., almost half is used for agricultural areas, and almost half of the human population inhabits urban ecosystems (FAOSTAT, 2014). The consequences of human impact for biodiversity and ecosystem service delivery vary both qualitatively and quantitatively depending on system properties and land-use intensities. Consequently the management options to sustainably supply ecosystem services vary as much, requiring ecologists to widen the kind of ecological systems studied beyond the traditional domain of ecology. Intensive agricultural management, for example, may lead to high crop yields (final services), but intensively managed fields often have simplified communities of service-providing units and hence low levels of intermediate services such as biological control by natural enemies or pollination (Médiène et al., 2011). To increase final service delivery, but also to compensate for the loss of intermediate services, anthropogenic management is often intensified (e.g., pesticide application; Médiène et al., 2011). Given the negative environmental externalities of some intensive management strategies (e.g., groundwater pollution and resource depletion), alternative management strategies that integrate intermediate services by promoting service-providing units are an opportunity to sustainably ensure crop production and to reduce reliance on anthropogenic interventions (Bommarco et al., 2013). Only a comprehensive perspective, that considers the response of all components of agricultural systems (biodiversity, intermediate, and final ecosystem services) to management will help to communicate the overarching importance of ecosystem service management. Urbanization, as a second example, may lead to increases in plant diversity as a consequence of increased habitat heterogeneity, but due to habitat fragmentation negatively affect species that rely on large habitats (Kowarik, 2011). Urban planning that considers the installation of green infrastructure in cities such as street trees and parks may benefit biodiversity and numerous ecosystem services (e.g., air filtration, water regulation, and noise reduction; Bolund and Hunhammar, 1999). Ecologists can directly contribute to ecosystem service research and support policy decisions, not only by evaluating human impact, but also by proposing anthropogenic interventions to benefit service-providing units and ecosystem services.

From a landscape perspective, the expansion of sites under human land use (e.g., agricultural fields, pastures and urban areas) at the cost of losing (semi-)natural land may lead to landscape simplification and fragmentation (Tscharntke et al., 2005). In agricultural landscapes, for instance, arable fields provide the final service of crop production, but constitute disturbed and ephemeral habitats, while many species associated with intermediate services (e.g., pollinators or biocontrol agents) depend on less disturbed habitats in the surrounding landscape (e.g., hedges or uncultivated field borders; see also challenge 4 and Table 2). Wild bees are one such example (Garibaldi et al., 2013), as these service providers maintain higher levels of crop pollination in the vicinity of semi-natural habitats (Garibaldi et al., 2011). Such context dependency has also been shown for biological control, which is predicted to be higher in more complex landscapes (Bianchi et al., 2006). Hence, to account for complex interactions with complementary habitat types or non-linear relationships to habitat area (Jauker et al., 2009, see also Hauck et al., 2013), a simple mapping from the extent of different habitat types may not suffice, but instead a spatially explicit landscape perspective on ecosystem services is needed.

\section{CHALLENGE 2: ASSESSING ECOSYSTEM SERVICES}

Instruments for assessing ecosystem services, including quantification, mapping and modeling, are a matter of debate in ecosystem service research (e.g., Carpenter et al., 2009; Feld et al., 2009; Hou et al., 2013). From the perspective of an ecologist 


\section{Table 2 | Examples for biological control measures from the literature and proposed categorization in service-providing units, ecosystem} modification (e.g., an agricultural field) and landscape modification (i.e., an agricultural landscape; see also challenge 2).

\begin{tabular}{|c|c|c|}
\hline Category & Measure & References \\
\hline \multirow{6}{*}{$\begin{array}{l}\text { Service- } \\
\text { providing } \\
\text { units* }^{*}\end{array}$} & Predator density & Menalled et al., 1999; Letourneau et al., 2009 \\
\hline & Pest density & Mols et al., 2007 \\
\hline & Predator richness & Duelli and Obrist, 2003 \\
\hline & Species composition of pests and predators & Bastian et al., 2013 \\
\hline & Pest consumption rates & Ingegno et al., 2013; Shrestha and Parajulee, 2013 \\
\hline & Pest reduction & Schmidt et al., 2003; Diehl et al., 2013 \\
\hline \multirow{7}{*}{$\begin{array}{l}\text { Ecosystem } \\
\text { modification }\end{array}$} & Farming system & Östman et al., 2003 \\
\hline & Pesticide use & Geiger et al., 2010; Médiène et al., 2011 \\
\hline & Fertilization regime & Birkhofer et al., 2008; Médiène et al., 2011 \\
\hline & Tillage regime & Médiène et al., 2011; Rusch et al., 2012 \\
\hline & Habitat complexity (e.g., crop diversification, plant structure) & $\begin{array}{l}\text { Cortesero et al., 2000; Langellotto and Denno, 2004; Médiène et al., } \\
2011\end{array}$ \\
\hline & Crop identity & Diehl et al., 2013 \\
\hline & Presence of nest boxes for insectivorous birds & Mols et al., 2007 \\
\hline \multirow{4}{*}{$\begin{array}{l}\text { Landscape } \\
\text { modification }\end{array}$} & Landscape complexity & Bianchi et al., 2006; Chaplin-Kramer et al., 2011 \\
\hline & Landscape patchiness & Bianchi et al., 2006 \\
\hline & Percentage of semi-natural habitats (e.g., fallows, field margins) & Bianchi et al., 2006; Rusch et al., 2012; Veres et al., 2013 \\
\hline & Percentage of woody habitats (e.g., woodlands, hedgerows) & Bianchi et al., 2006; Rusch et al., 2012; European Commission, 2014 \\
\hline
\end{tabular}

*Includes organisms which are positively (e.g., predators) or negatively related (e.g., pests) to service provision.

challenges in assessing ecosystem services arise from the need (i) to evaluate relationships between services and the kind of measures usually collected in ecological studies (e.g., species richness) and (ii) to account for the characteristics of ecological processes (e.g., dynamics, feedbacks, and uncertainties) in statistical models focusing on service provision.

Final ecosystem services are often directly assessed, but such assessment does not provide information about contributing ecological processes or how management could be adapted to increase service provision. A mechanistic understanding of relationships between management and ecosystem services is required to transfer management recommendation outside the context where data were collected. This includes the assessment of the contribution of intermediate ecosystem services and how they are affected by management. The assessment of intermediate services is often more costly and time-consuming than for final services. This partly stems from the lack of proxies for ecological functions and the fact that links between ecosystem functions and final services may be context dependent, e.g., depend on spatial association (Tixier et al., 2013) or ecosystem type (Feld et al., 2009). Measures used to assess intermediate services include direct measures of intermediate services (e.g., pollination success; Kremen et al., 2002), indicators of service provision (e.g., dung removal by dung beetles; Gollan et al., 2013) and proxies that are indirectly linked to ecosystem services (e.g., proportion of semi-natural habitats in the surrounding of a focal field; Rusch et al., 2012). During the past decade, there has been considerable effort in developing instruments to perform assessments of ecosystem services, but measuring ecosystem services based on scientific standards is still not trivial (Carpenter et al., 2009).
For instance, predator species richness has been used to indicate levels of biological control (e.g., Duelli and Obrist, 2003), even though the effect of predator richness on prey is still debated (Bruno and Cardinale, 2008). The direct quantification of intermediate services is challenging, as complex biotic interactions and environmental conditions may alter service provision. Biological control of arable weeds can, for example, be estimated by quantifying seed removal from seed cards (e.g., Jonason et al., 2013). However, such estimates are difficult to scale up to a whole field or farm. Pollination of potted plants, so called phytometers, is a promising technique to estimate pollination potential (Woodcock et al., 2014), but uncertainty remains about how the pollination success of a small number of potted plants reflects pollination of crops (cf. Sih and Baltus, 1987). Ecologists, in collaboration with agricultural and forest scientists, thus need to identify scientifically sound ecological measures that are reliable indicators of ecosystem service provision.

As a first and simple step to account for the characteristics of processes underlying service provision, it is suggested here to choose among a small set of measures that form joint, reliable indicators of an individual service. The following example illustrates why the selection of a set of indicators may be superior to the use of a single indicator using the ecosystem service of biological control (see also Kandziora et al., 2013). Processes underlying the service of biological control are related to service-providing units (predators and parasitoids), units that provide a disservice (pests; Letourneau et al., 2009) and both groups of organisms are altered by anthropogenic interventions at the spatial scale of fields (Médiène et al., 2011) and landscapes (Bianchi et al., 2006). The assessment of biological control may therefore be improved 
if a small set of selected measures is included that covers aspects of service and disservice-providing units (e.g., pest consumption rates), ecosystem management (e.g., insecticide applications) and landscape modification (e.g., proportion of semi-natural habitats in the surrounding landscape; Table 2). Consideration of abiotic variables such as climate (Diehl et al., 2013) or soil characteristics (Birkhofer et al., 2008) will add to the explanatory power of this set of measures.

Ecosystem service research is particularly focused on predicting the consequences of future management options. Statistical models can be used to identify driving forces of changes in service provision and to predict system shifts and fluctuations in service provision as a consequence of environmental change and anthropogenic intervention (Evans et al., 2012). Simple statistical models (e.g., regression) are based on interpolations along existing gradients and cannot provide predictions about levels of ecosystem services under future conditions outside of these gradients. In contrast, process-based models are based on the assumption that essential features of ecological processes can be extrapolated to conditions not currently observed. These models rely on knowledge about the dynamics of ecological processes, i.e., intermediate ecosystem services, including interactions, feedbacks, and uncertainties (Nicholson et al., 2009). For example, models based on the food and nestling requirement of bees can be used to predict pollinator abundance across landscapes because fundamental assumptions about bee behavior hold under novel conditions (Kennedy et al., 2013). In this context, climatic conditions deserve particular attention, since climate change will have a strong impact on service-providing units, intermediate and final ecosystem services (Montoya and Raffaelli, 2010; Birkhofer and Wolters, 2012; Diehl et al., 2013). Predictions of future changes will only be possible if studies address this aspect by using mechanistic models (e.g., Schröter et al., 2005; Jönsson et al., 2014a). For example, recommendations about forest management under a changing climate can be based on a dynamic vegetation model that uses basic characteristics of tree growth to predict consequences of alternative silvicultural regimes (Jönsson et al., 2014b). However, mechanistic models are never better than the theories and empirical data underpinning them and the development of models with predictive power is a challenge for ecologists.

The quantification of uncertainty in predictive modeling requires critical evaluation (Cheaib et al., 2012) and ecologists need to account for uncertainty particularly if (i) multiple sources contribute to uncertainty (e.g., model and parameter uncertainty; Barry and Elith, 2006), (ii) uncertainties result from combinations of different sources (e.g., statistical relationships and expert knowledge; Krueger et al., 2012) and (iii) new information necessitates an update of the models (e.g., in Bayesian frameworks; Ricketts et al., 2008). Mapping of ecosystem services is fraught with multiple uncertainties stemming from uncertainty in the ability to capture relevant processes as well as translating and scaling mapped information (Hou et al., 2013). The evaluation of uncertainty, the integration of knowledge about evolutionary aspects and human impacts into the development of processbased models and their coupling with socio-economic models are important fields of future research to which ecologists need to contribute (e.g., Polce et al., 2013; Van der Biest et al., 2014).

\section{CHALLENGE 3: ANALYZING RELATIONSHIPS BETWEEN ECOSYSTEM SERVICES}

Ecosystem services may demonstrate joint variation, either synergistic or antagonistic, in space and time. The interpretation of such patterns between multiple ecosystem services (more than two) has become an intensively debated subject (Cimon-Morin et al., 2013) and multi-ecosystem service models that link service provision and trade-offs are rapidly emerging (for a review see Nelson and Daily, 2010). Such joint variation may also concern relationships between beneficial ecosystem services and so called ecosystem disservices, for example environmental externalities such as water pollution (Zhang et al., 2007). Ecologists can contribute to the analyses of joint variation of services and disservices by identifying the underlying mechanisms that explain relationships between services and their response patterns to environmental change. For instance, the marginal contribution of enhancing pollination on crop yield may partly depend on the level of other ecosystem services, with highest yield under a simultaneous increase of pollination and biological control (Bos et al., 2007; Lundin et al., 2013). Rodríguez et al. (2006) and Bennett et al. (2009) argued that it will only be possible to make informed decisions and avoid unexpected outcomes if relationships between services are better understood. Alterations of a single ecosystem service by agricultural management can, for example, have unintended effects on other services and a better understanding of such unexpected relationships will safeguard human societies against the consequences of sudden regime-shifts in ecosystems (e.g., Gordon et al., 2008).

Improving the understanding of the relationships between ecosystem services poses two major challenges to ecological research: (i) drawing conclusions about relationships between ecosystem services by understanding if relationships are indirect through shared environmental drivers or direct because one ecosystem services causally affects another and (ii) solving issues of visualization and statistical testing when analyzing relationships between multiple (more than two) ecosystem services.

To be able to predict the consequences of environmental change as drivers of changes in ecosystem services, it is important to distinguish between indirect and direct relationships (Bennett et al., 2009; Lautenbach et al., 2010). Both direct relationships (if services are related to each other) and indirect relationships (if services are related through a driver) can lead to synergies and trade-offs between the services (Bennett et al., 2009). Ecosystem services may be directly and causally linked, because one ecosystem service directly interacts with another ecosystem services (Figure 1A, direct relationships). For example, fertility of agricultural soils (service 1) is directly and positively linked to crop yields (service 2; Lal, 2005). Given this direct relationship and assuming the absence of other driving forces, a manipulation of one service (e.g., increase soil fertility by adding manure) would directly increase or decrease the second service (e.g., increase crop yield). However, ecosystem services may be statistically associated, negatively or positively, because their underlying drivers are related (Figure 1B; indirect relationship). Water retention (service 1 ) and landscape beauty (service 2 ), for example, may be statistically associated, because the proportion of urban area that reduces water retention (driver 1) may be negatively related to 


\section{A Direct relationship}

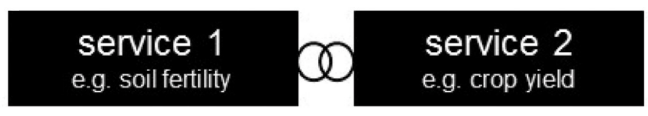

B Indirect relationship, correlated drivers

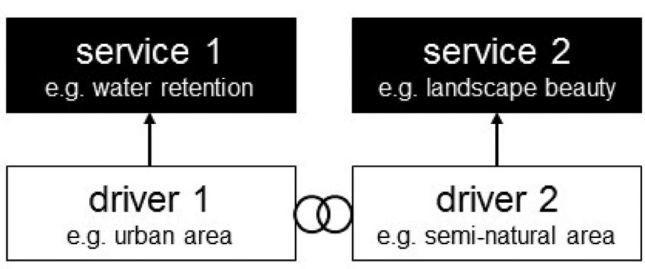

C Indirect relationship, shared driver

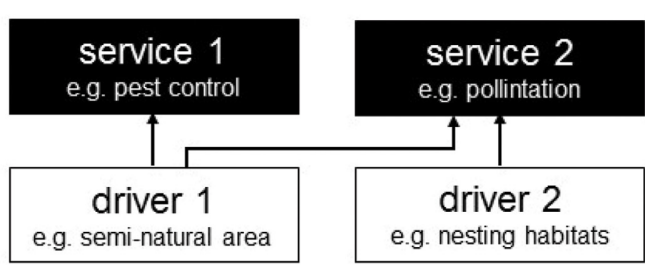

FIGURE 1 | Potential relationships between two ecosystem services (service 1 and service 2). (A) Direct relationships between ecosystem services and indirect relationships via (B) two associated drivers or (C) a shared driver.

the proportion of semi-natural land (driver 2; Raudsepp-Hearne et al., 2010) that increases landscape beauty. In this case, manipulation of one service (e.g., increasing water retention by leaving out joints between paving stones in urban areas), will not affect the second service (e.g., landscape beauty). In contrast, manipulation of one driver (e.g., reduce the area of semi-natural land), may affect the second driver (e.g., increase the proportion of urban areas) in the absence of other drivers (e.g., other landuse types) and thereby affect both services (e.g., reduce water retention and landscape beauty). Finally, services may also be correlated because of independent responses to a common driver (Figure 1C, indirect relationship). Pollination of crop plants (service 1) and pest control in crop fields (service 2), for example, are both increased by the proportion of semi-natural habitats surrounding crop fields (driver 1; Bianchi et al., 2006; Garibaldi et al., 2011). In addition, pollination is affected by the proportion of nesting habitats (driver 2; Ricketts et al., 2008). Given this indirect relationship, increasing one service (e.g., pest control by augmentation of natural enemies) would not affect the other service (e.g., pollination). Manipulating the shared driver (e.g., increasing the availability of semi-natural habitats around a focal field by sowing flowering strips), will increase both services (e.g., pollination and pest control), while affecting the non-shared driver (e.g., availability of nesting habitats) will only affect one service (e.g., pollination).

In the literature, both types of relationships are frequently labeled "interactions" independent of their correlative or causal nature (Seppelt et al., 2011). Services that show comparable or contrasting responses are then characterized in terms of synergies or trade-offs and grouped as "bundles" (Raudsepp-Hearne et al., 2010). It is without doubt important to describe relationships between multiple services independent of what causes statistical associations (Tallis et al., 2008; Power, 2010; Maskell et al., 2013). However, the ability to manage situations in which multiple drivers act on multiple services would benefit from an improved understanding of the relationships between individual services (indirect or direct), their relationships to drivers and the processes that affect both relationships (Lautenbach et al., 2010). To manage ecosystem service provisioning, planners and decision-makers need to know if ecosystem services respond to a shared driver or if services are directly linked to each other. If services respond independently, but contrastingly to a single shared driver, better ecological understanding of the individual relationships between the driver and the services will help to identify management strategies that mitigate trade-offs between services. If services are directly linked to each other, improving management becomes more complicated as in addition to the relationship between services and the driver, interactions between services need to be considered. We therefore encourage ecologists to not only investigate the relationship between services and various drivers, but to also test for direct relationships between multiple ecosystem services. Conclusions about direct links between ecosystem services can be derived from studies using large, replicated datasets in approaches that implicitly model direct and indirect effects of anthropogenic interventions on service provision (e.g., structural equation models, Gamfeldt et al., 2013), but also from direct experimental tests of ecosystem service relationships (e.g., Lundin et al., 2013). Together, these approaches, coupled with the development of mechanistic models (e.g., InVEST model, http://www. naturalcapitalproject.org), will contribute to an improved management of ecosystems for the provision of multiple services in the future (Tixier et al., 2013).

To study relationships between two or three ecosystem services techniques such as correlation analysis (Figure 2A; e.g., Raudsepp-Hearne et al., 2010) or linear mixed effect models (Figure 2B; e.g., De Vries et al., 2013) can be used. Efficiency frontier analyses (Nelson et al., 2008) or landscape optimization approaches (Lautenbach et al., 2010) are then often used to identify solutions for the simultaneous provision of services. It may be important to consider multiple services in the same analytical framework, as it is likely that most services observed in a study are related to each other. Simple spider web or flower diagrams can be used to illustrate relationships between several services (Figure 2C; e.g., Foley et al., 2005). For the purpose of relating multiple services to drivers in a single analytical framework, the frequent use of principal component analysis is notable (Figure 2D; e.g., Raudsepp-Hearne et al., 2010; Maes et al., 2011; Maskell et al., 2013; Martín-López et al., 2014). However, since relationships between ecosystem services in response to a driver can be non-linear, asymptotic, unimodal or characterized by tipping points (e.g., Maskell et al., 2013), it should be noted that the quality of principal component analysis entirely depends on if relationships between variables are linear (McCune et al., 2002). The use of this method should therefore be constraint to datasets 
A

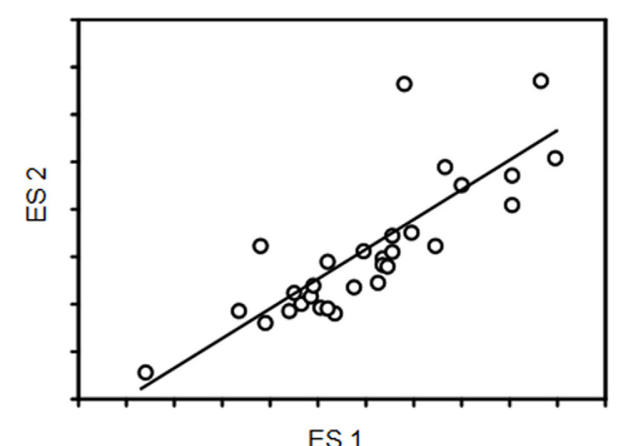

C

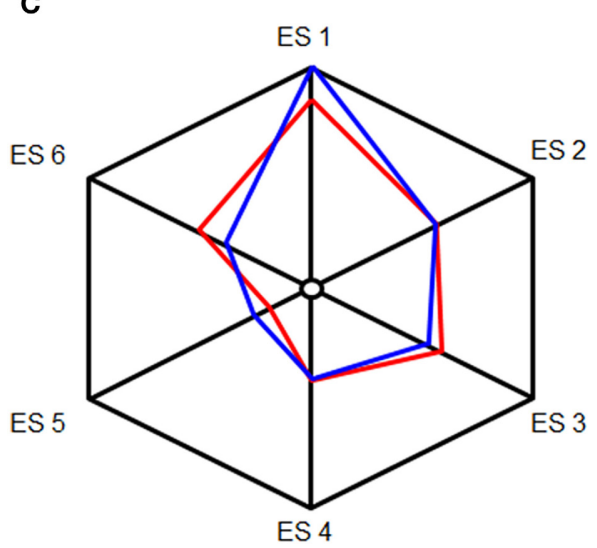

FIGURE 2 | Common approaches to study relationships between ecosystem services with (A) correlation analysis between two services (ES1, ES2), (B) a three dimensional surface plot that shows the modeled relationship between three services (ES1, ES2, ES3), (C) a spider web plot showing the relationship between six services in
B

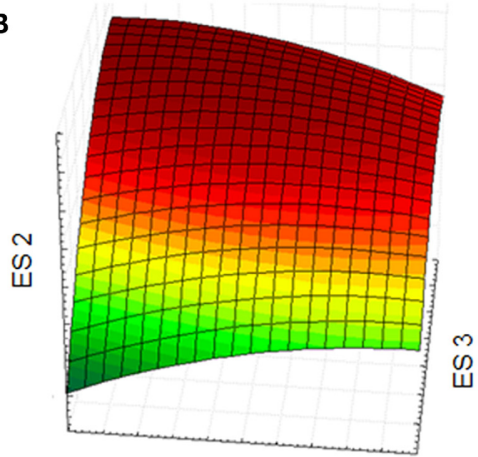

ES 1

D

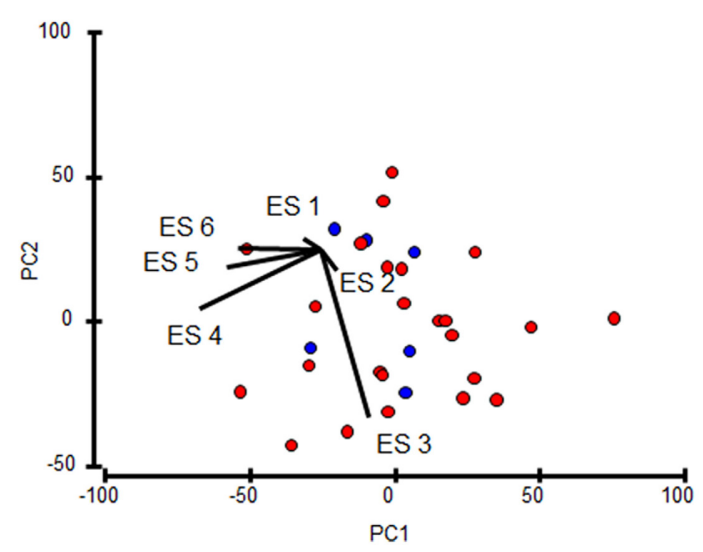

two land-use types (different colors; ES1, ES2, ES3, ES4, ES5, ES6) and (D) a principal component analysis showing the relationship between six services (vectors; ES1, ES2, ES3, ES4, ES5, ES6) in the ordination graph for sites of two different land-use types (different colors). in which relationships between multiple services are approximately linear (see also Quinn and Keough, 2002). Among the alternative methods to visualize trade-offs between multiple services in one analytical framework, principal coordinates analysis holds potential as it allows for the analysis of non-linear relationships (Legendre and Legendre, 2012). Partial least squares regression is another promising technique to analyze relationships between intermediate ecosystem services based on empirical data (e.g., Haenlein and Kaplan, 2004).

\section{CHALLENGE 4: CONSIDERING APPROPRIATE SPATIAL AND TEMPORAL SCALES}

Scale is a contentious issue in ecosystem service research, because ecological processes are fundamentally scale dependent (Levin, 1992) and a large number of diverging approaches to study spatial scales in ecological research adds to this complexity (e.g., Blackburn and Gaston, 2002). This potentially impedes the integration of different research fields (e.g., Lima and Zollner, 1996) particularly in a multidisciplinary context such as ecosystem service research (Cumming et al., 2013). Compared to spatial scales, temporal aspects have received remarkably little attention in ecosystem service research (Kremen, 2005). Most of the existing ecological knowledge on ecosystem processes is based on investigations covering short periods of time (e.g., Cardinale et al., 2009). A better understanding of the (i) spatial and (ii) temporal scales at which the provision of ecosystem services is affected by environmental change or anthropogenic interventions is needed to satisfy the growing public and political demand for sustainable land use (Tilman et al., 2002).

It is a major challenge for ecologists to scale up from experimental plots to scales that are relevant for the management of most ecosystem services (Cardinale et al., 2012; Figure 3). These plot-level studies can often not account for the heterogeneity of complex landscapes and therefore may not provide adequate empirical data about ecosystem service provision from major land-use types in a landscape. Studies relating biodiversity to ecosystem services often focus on ecological processes and intermediate ecosystem services at small spatial scales (Cardinale et al., 2012). In contrast, research on spatial prioritizations for the protection of ecosystem services (Luck et al., 2012) is biased toward services providing benefits at large spatial scales. This suggests that there is a mismatch between species-oriented ecological research dealing with mechanisms underlying the provision of services, and conservation-oriented research identifying 


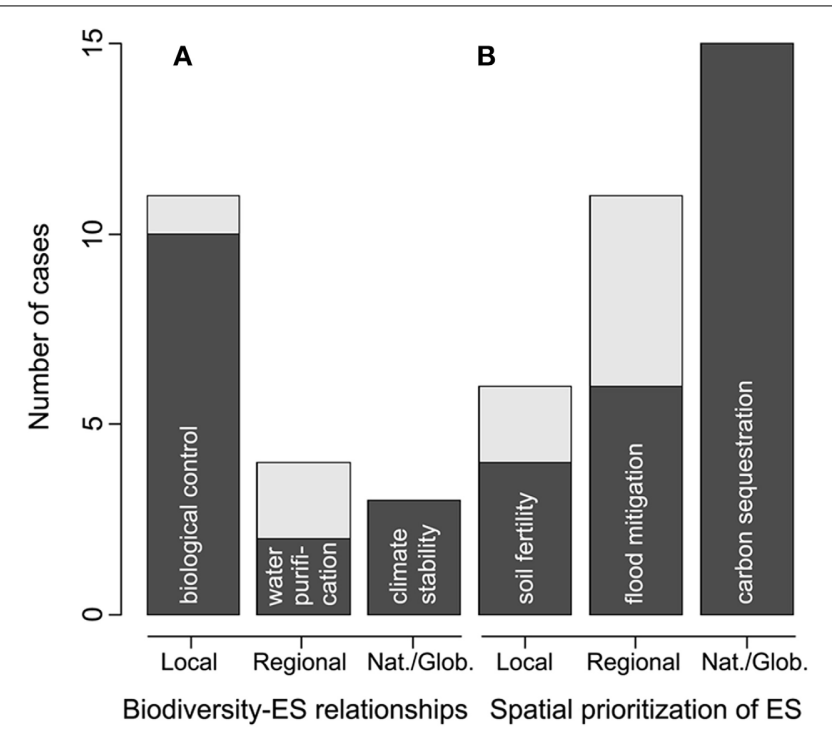

FIGURE 3 | Number of published cases analyzing (A) regulating and supporting ecosystem services with respect to biodiversity-ecosystem service relationships, and (B) spatial prioritization of ecosystem services. Number of cases based on number of syntheses presented in Cardinale et al. (2012) (A) and number of assessments in Luck et al. (2012) (B) respectively. Ecosystem services are classified according to the spatial scale at which ecological processes are linked to human benefits (local, regional or national/global; Kremen, 2005; Hein et al., 2006). The dark part of bars represents the most dominant ecosystem service among all cases/studies at a particular scale.

hotspots in space for particular services (Figure 3). Coupling these two research approaches is critically important to improve the understanding of ecosystem service provision across real landscapes.

The scale of ecological processes is relevant to ecosystem service research, because of the need to account for the spatial relationship between generation and consumption of ecosystem services (Fisher et al., 2009). One approach to account for this goal is based on spatially explicit modeling of ecological production functions (e.g., Kremen et al., 2007; Nelson et al., 2009; Jonsson et al., 2014). In addition, ecological functions underlying final ecosystem services may depend on the spatial scale at which management is applied (cf. Leibold et al., 2004). This generates context dependent responses of management interventions (Tscharntke et al., 2012). For example, populations of serviceproviding units may only maintain viable sizes given that enough habitats are preserved across multiple land-owners (Drechsler et al., 2010). Hence, to optimize ecosystem service provision at larger spatial scales, the identification of conditions under which land-owners benefit from co-operation will be an important future topic in ecosystem services research (e.g., Stallman, 2011; Sutherland et al., 2012; Cong et al., 2014). In addition, ecological research needs to cover the relevant spatial scales at which multiple ecosystem services are efficiently managed (see also Mastrangelo et al., 2014). Scaling up models for individual ecosystem services in space is certainly one of the major challenges (Stuart and Gillon, 2013), but it is also crucial to account for relationships between services that are caused by interactions between services or anthropogenic interventions at different spatial scales (e.g., management by farmers at local scales and policy makers at broader scales, Tixier et al., 2013; see also challenge 3.3).

It is essential to understand the temporal dynamics of service provision for the development of sustainable management and conservation strategies. For example, the quality of provision of an ecosystem service may not only depend on its average provision over time, but also on its variation over time (Mori et al., 2013). It is therefore important to assess the stability of ecosystem service provision in simplified ecosystems, where losses of ecosystem resilience to disturbances can be expected to be strongest (Bengtsson et al., 2003; Tscharntke et al., 2012). In addition, lageffects of management decisions may make ecosystem service losses only apparent a long time after the anthropogenic intervention (Millennium Ecosystem Assessment, 2005). Such lag-effects may be further accentuated by climate change, where loss of biodiversity may reduce resilience of critical functions (cf. Elmqvist et al., 2003). We therefore need long-term estimates of ecosystem service provision to better understand how inter-annual variation in environmental conditions, such as climate change, affects the magnitude and stability of service provision. However, the timespan of ecological research is often constrained to a few years due to generally short funding periods. Such short research periods will fail to provide reliable estimates of altered behavior of serviceproviding units in response to climate change (e.g., Mooney et al., 2009). The few long-term studies, such as the Cedar Creek experiment in the US (Siemann et al., 1998) or the Biodiversity Exploratories in Germany (Fischer et al., 2010), deliver fundamental insights into biodiversity and ecosystem functioning over longer temporal scales. We call for more such approaches to get a better understanding of both long-term changes and temporal variability of ecosystem service provision.

\section{CONCLUDING REMARKS}

Although the ecosystem service concept is based on an ecological understanding of ecosystems, ecologists are confronted with a range of challenges when researching ecosystem services. This is partly explained by the wide variety of terms and definitions from different scientific disciplines as well as a lack of generally accepted assessment methods, difficulties with analytical and modeling methods and mismatches of spatial and temporal scales between service provision and anthropogenic interventions. Ecologists need to adapt their perspective and methods to a larger societal context for the improvement of ecosystem service research. Particular emphasis needs to be directed toward supporting decision makers with relevant information about service-providing units and mechanisms underlying the provision of services at appropriate temporal and spatial scales. To conclude, ecosystem service research is challenging for ecologists, but developing a multifaceted understanding of how nature promotes human well-being is crucial for the sustainable use of the earth's resources. Ecosystem service research offers ecologists the unique opportunity to act as promoters for the understanding of how to conserve and sustain benefits gained from nature. 


\section{AUTHOR CONTRIBUTIONS}

All authors contributed to the manuscript by reviewing literature, discussing and developing ideas during two workshops, writing text sections and revising sections written by other authors. Eva Diehl and Klaus Birkhofer had the initial idea for the manuscript and wrote general parts of the manuscript (abstract, introduction and conclusion) together with Henrik G. Smith. Henrik G. Smith and Volkmar Wolters contributed to all sections in the manuscript. Andrea Früh-Müller contributed to challenge 4. Eva Diehl contributed to challenges 1-3. Franziska Machnikowski contributed to the introduction and challenge 4. Jesper Andersson contributed to the introduction. Johan Ekroos contributed to challenge 4. Klaus Birkhofer contributed to challenges 2-3. Keiko Sasaki contributed to the introduction and challenges 2-3. Lovisa Nilsson contributed to challenges 1 and 4. Maj Rundlöf contributed to the introduction and challenge 2. Viktoria L. Mader contributed to challenges 1-2.

\section{ACKNOWLEDGMENTS}

We thank Johan G. Zaller, Quang Bao Le and Visa Nuutinen for very helpful comments that helped improving earlier versions of the manuscript. The strategic research environment BECC and the strong research environment SAPES funded by the Swedish research council Formas are greatly acknowledged for financial support. This article was written within the scope of the "ÖkoService" project and the "JAGUAR" project funded by the German Federal Ministry of Education and Research (BMBF).

\section{REFERENCES}

Barry, S., and Elith, J. (2006). Error and uncertainty in habitat models. J. Appl. Ecol. 43, 413-423. doi: 10.1111/j.1365-2664.2006.01136.x

Bastian, O., Grunewald, K., and Sybre, R. U. (2013). "Klassifikation von ÖSD," in Ökosystemdienstleistungen: Konzept, Methoden und Fallbeispiele, eds K. Grunewald and O. Bastian (Berlin: Springer Spektrum), 48-56.

Bengtsson, J., Angelstam, P., Elmqvist, T., Emanuelsson, U., Folke, C., Ihse, M., et al. (2003). Reserves, resilience and dynamic landscapes. Ambio 32, 389-396. doi: 10.1579/0044-7447-32.6.389

Bennett, E. M., Peterson, G. D., and Gordon, L. J. (2009). Understanding relationships among multiple ecosystem services. Ecol. Lett. 12, 1394-1404. doi: 10.1111/j.1461-0248.2009.01387.x

Bianchi, F., Booij, C., and Tscharntke, T. (2006). Sustainable pest regulation in agricultural landscapes: a review on landscape composition, biodiversity and natural pest control. Proc. Biol. Sci. 273, 1715-1727. doi: 10.1098/rspb. 2006.3530

Birkhofer, K., Bezemer, T. M., Bloem, J., Bonkowski, M., Christensen, S., Dubois, D., et al. (2008). Long-term organic farming fosters below and aboveground biota: implications for soil quality, biological control and productivity. Soil Biol. Biochem. 40, 2297-2308. doi: 10.1016/j.soilbio.2008.05.007

Birkhofer, K., and Wolters, V. (2012). The global relationship between climate, net primary production and the diet of spiders. Glob. Ecol. Biogeogr. 21, 100-108. doi: $10.1111 /$ j.1466-8238.2011.00654.x

Blackburn, T. M., and Gaston, K. J. (2002). Scale in macroecology. Glob. Ecol. Biogeogr. 11, 185-189. doi: 10.1046/j.1466-822X.2002.00290.x

Bolund, P., and Hunhammar, S. (1999). Ecosystem services in urban areas. Ecol. Econ. 29, 293-301. doi: 10.1016/S0921-8009(99)00013-0

Bommarco, R., Kleijn, D., and Potts, S. G. (2013). Ecological intensification: harnessing ecosystem services for food security. Trends Ecol. Evol. 28, 230-238. doi: 10.1016/j.tree.2012.10.012

Bos, M. B., Veddeler, D., Bogdanski, A. K., Klein, A. M., Tscharntke, T., SteffanDewenter, I., et al. (2007). Caveats to quantifying ecosystem services: fruit abortion blurs benefits from crop pollination. Ecol. Appl. 17, 1841-1849. doi: $10.1890 / 06-1763.1$
Boyd, J., and Banzhaf, S. (2007). What are ecosystem services? The need for standardized environmental accounting units. Ecol. Econ. 63, 616-626. doi: 10.1016/j.ecolecon.2007.01.002

Braat, L. C., and De Groot, R. (2012). The ecosystem services agenda: bridging the worlds of natural science and economics, conservation and development, and public and private policy. Ecosys. Serv. 1, 4-15. doi: 10.1016/j.ecoser.2012. 07.011

Bruno, J. F., and Cardinale, B. J. (2008). Cascading effects of predator richness. Front. Ecol. Environ. 6, 539-546. doi: 10.1890/070136

Cardinale, B., Duffy, J. E., Srivastava, D., Loreau, M., Thomas, M., and Emmerson, M. (2009). "Towards a food web perspective on biodiversity and ecosystem functioning," in Biodiversity, Ecosystem Functioning, and Human Wellbeing. An Ecological and Economic Perspective, ed S. Naeem (Oxford, New York: Oxford University Press), 105-120. doi: 10.1093/acprof:oso/9780199547951.003.0008

Cardinale, B. J., Duffy, J. E., Gonzalez, A., Hooper, D. U., Perrings, C., Venail, P., et al. (2012). Biodiversity loss and its impact on humanity. Nature 486, 59-67. doi: 10.1038/nature11148

Carpenter, S. R., Mooney, H. A., Agard, J., Capistrano, D., DeFries, R. S., Díaz, S., et al. (2009). Science for managing ecosystem services: beyond the millennium ecosystem assessment. Proc. Natl. Acad. Sci. U.S.A. 106, 1305-1312. doi: 10.1073/pnas.0808772106

CBD. (2010). COP 10 Decision X/2: The Strategic Plan for Biodiversity 20112020 and the Aichi Biodiversity Targets. Available online at: http://www.cbd.int/ $\mathrm{decision} / \mathrm{cop} / \mathrm{?id}=12268$

Chaplin-Kramer, R., O’Rourke, M. E., Blitzer, E. J., and Kremen, C. (2011). A metaanalysis of crop pest and natural enemy response to landscape complexity. Ecol. Lett. 14, 922-932. doi: 10.1111/j.1461-0248.2011.01642.x

Cheaib, A., Badeau, V., Boe, J., Chuine, I., Delire, C., Dufrêne, E., et al. (2012). Climate change impacts on tree ranges: model intercomparison facilitates understanding and quantification of uncertainty. Ecol. Lett. 15, 533-544. doi: 10.1111/j.1461-0248.2012.01764.x

Cimon-Morin, J., Darveau, M., and Poulin, M. (2013). Fostering synergies between ecosystem services and biodiversity in conservation planning: a review. Biol. Conserv. 166, 144-154. doi: 10.1016/j.biocon.2013.06.023

Cong, R. G., Smith, H. G., Olsson, O., and Brady, M. (2014). Managing ecosystem services for agriculture: will landscape-scale management pay? Ecol. Econ. 99, 53-62. doi: 10.1016/j.ecolecon.2014.01.007

Cortesero, A. M., Stapel, J. O., and Lewis, W. J. (2000). Understanding and manipulating plant attributes to enhance biological control. Biol. Control 17, 35-49. doi: 10.1006/bcon.1999.0777

Costanza, R., d'Arge, R., De Groot, R., Farberk, S., Grasso, M., Limburg, K., et al. (1997). The value of the world's ecosystem services and natural capital. Nature $387,253-260$.

Cumming, G. S., Olsson, P., Chapin, F. S. III, and Holling, C. S. (2013). Resilience, experimentation, and scale mismatches in social-ecological landscapes. Landscape Ecol. 28, 1139-1150. doi: 10.1007/s10980-012-9725-4

Daily, G. C. (1997). Nature's Services. Societal Dependence on Natural Ecosystems. Washington, DC: Island Press.

Daily, G. C., Polasky, S., Goldstein, J., Kareiva, P. M., Mooney, H. A., Pejchar, L., et al. (2009). Ecosystem services in decision making: time to deliver. Front. Ecol. Environ. 7, 21-28. doi: 10.1890/080025

De Groot, R. (2006). Function-analysis and valuation as a tool to assess land use conflicts in planning for sustainable, multi-functional landscapes. Landsc. Urban Plan. 75, 175-186. doi: 10.1016/j.landurbplan.2005.02.016

De Groot, R., Alkemade, R., Braat, L., Hein, L., and Willemen, L. (2010). Challenges in integrating the concept of ecosystem services and values in landscape planning, management and decision making. Ecol. Complex. 7, 260-272. doi: 10.1016/j.ecocom.2009.10.006

De Groot, R., Wilson, M. A., and Boumans, R. M. (2002). A typology for the classification, description and valuation of ecosystem functions, goods and services. Ecol. Econ. 41, 393-408. doi: 10.1016/S0921-8009(02)00089-7

De Vries, F. T., Thebault, E., Liiri, M., Birkhofer, K., Tsiafouli, M. A., Bjornlund, L., et al. (2013). Soil food web properties explain ecosystem services across European land use systems. Proc. Natl. Acad. Sci. U.S.A. 110, 14296-14301. doi: $10.1073 /$ pnas. 1305198110

Diehl, E., Sereda, E., Wolters, V., and Birkhofer, K. (2013). Effects of predator specialization, host plant and climate on biological control of aphids by natural enemies: a meta-analysis. J. Appl. Ecol. 50, 262-270. doi: 10.1111/13652664.12032 
Drechsler, M., Wätzold, F., Johst, K., and Shogren, J. F. (2010). An agglomeration payment for cost-effective biodiversity conservation in spatially structured landscapes. Resour. Energy Econ. 32, 261-275. doi: 10.1016/j.reseneeco.2009.11.015

Duelli, P., and Obrist, M. K. (2003). Biodiversity indicators: the choice of values and measures. Agric. Ecosyst. Environ. 98, 87-98. doi: 10.1016/S01678809(03)00072-0

Millennium Ecosystem Assessment. (2005). Ecosystems and Human Well-being. General Synthesis: a Report of the Millennium Ecosystem Assessment. Washington, DC: Island Press.

Ehrlich, P. R., and Ehrlich, A. H. (1981). Extinction. The Causes and Consequences of the Disappearance of Species. New York, NY: Random House.

Ekroos, J., Olsson, O., Rundlöf, M., Wätzold, F., and Smith, H. G. (2014). Optimizing agri-environment schemes for biodiversity, ecosystem services or both? Biol. Conserv. 172, 65-71. doi: 10.1016/j.biocon.2014.02.013

Elmqvist, T., Folke, C., Nystrom, M., Peterson, G., Bengtsson, J., Walker, B., et al. (2003). Response diversity, ecosystem change, and resilience. Front. Ecol. Environ. 1, 488-494. doi: 10.1890/15409295(2003)001[0488:RDECAR]2.0.CO;2

Engel, S., Pagiola, S., and Wunder, S. (2008). Designing payments for environmental services in theory and practice: an overview of the issues. Ecol. Econ. 65, 663-674. doi: 10.1016/j.ecolecon.2008.03.011

European Commission. (2014). Mapping and Assessment of Ecosystems and their Services - Indicators for Ecosystem Assessments under Action 5 of the EU Biodiversity Strategy to 2020.

Evans, M. R., Norris, K. J., and Benton, T. G. (2012). Predictive ecology: systems approaches. Philos. Trans. R. Soc. B 367, 163-169. doi: 10.1098/rstb. 2011.0191

FAOSTAT. Food and Agriculture Organization of the United Nations (2014). Resources - Land (Land area 2011). The Statistics Division of the FAO. Available online at: http://faostat.fao.org/

Feld, C. K., Martins da Silva, P., Paulo Sousa, J., De Bello, F., Bugter, R., Grandin, U., et al. (2009). Indicators of biodiversity and ecosystem services: a synthesis across ecosystems and spatial scales. Oikos 118, 1862-1871. doi: 10.1111/j.16000706.2009.17860.x

Fischer, M., Bossdorf, O., Gockel, S., Hänsel, F., Hemp, A., Hessenmöller, D., et al. (2010). Implementing large-scale and long-term functional biodiversity research: the biodiversity exploratories. Basic Appl. Ecol. 11, 473-485. doi: 10.1016/j.baae.2010.07.009

Fisher, B., Turner, R. K., and Morling, P. (2009). Defining and classifying ecosystem services for decision making. Ecol. Econ. 68, 643-653. doi: 10.1016/j.ecolecon.2008.09.014

Foley, J. A., DeFries, R., Asner, G. P., Barford, C., Bonan, G., Carpenter, S. R., et al. (2005). Global consequences of land use. Science 309, 570-574. doi: $10.1126 /$ science. 1111772

Früh-Müller, A. J., Wegmann, M., and Koellner, T. (2014). Flood exposure and settlement expansion since pre-industrial times in 1850 until 2011 in north Bavaria, Germany. Reg. Environ. Change. doi: 10.1007/s10113-014-0657-1

Gamfeldt, L., Snäll, T., Bagchi, R., Jonsson, M., Gustafsson, L., Kjellander, P., et al. (2013). Higher levels of multiple ecosystem services are found in forests with more tree species. Nat. Commun. 4, 1340. doi: 10.1038/ncomms2328

Garibaldi, L. A., Steffan-Dewenter, I., Kremen, C., Morales, J. M., Bommarco, R., Cunningham, S. A., et al. (2011). Stability of pollination services decreases with isolation from natural areas despite honey bee visits. Ecol. Lett. 14, 1062-1072. doi: 10.1111/j.1461-0248.2011.01669.x

Garibaldi, L. A., Steffan-Dewenter, I., Winfree, R., Aizen, M. A., Bommarco, R., Cunningham, S. A., et al. (2013). Wild pollinators enhance fruit set of crops regardless of honey bee abundance. Science 339, 1608-1611. doi: 10.1126/science. 1230200

Geiger, F., Bengtsson, J., Berendse, F., Weisser, W. W., Emmerson, M., Morales, M. B., et al. (2010). Persistent negative effects of pesticides on biodiversity and biological control potential on European farmland. Basic Appl. Ecol. 11, 97-105. doi: 10.1016/j.baae.2009.12.001

Gollan, J. R., De Bruyn, L. L., Reid, N., and Wilkie, L. (2013). Monitoring the ecosystem service provided by dung beetles offers benefits over commonly used biodiversity metrics and a traditional trapping method. J. Nat. Conserv. 21, 183-188. doi: 10.1016/j.jnc.2012.12.004

Gordon, L. J., Peterson, G. D., and Bennett, E. M. (2008). Agricultural modifications of hydrological flows create ecological surprises. Trends Ecol. Evol. 23, 211-219. doi: 10.1016/j.tree.2007.11.011
Haenlein, M., and Kaplan, A. M. (2004). A beginner's guide to partial least squares analysis. Understand. Stat. 3, 283-297. doi: 10.1207/s15328031us 0304

Hails, R. S., and Ormerod, S. J. (2013). Editorial: ecological science for ecosystem services and the stewardship of natural capital. J. Appl. Ecol. 50, 807-810. doi: 10.1111/1365-2664.12127

Haines-Young, R., and Potschin, M. (2010). "The links between biodiversity, ecosystem services and human well-being," in Ecosystem Ecology. A New Synthesis, eds D. G. Raffaelli and C. Frid (Cambridge, New York: Cambridge University Press), 110-139.

Hauck, J., Görg, C., Varjopuro, R., Ratamäki, O., and Jax, K. (2013). Benefits and limitations of the ecosystem services concept in environmental policy and decision making: some stakeholder perspectives. Environ. Sci. Policy 25, 13-21. doi 10.1016/j.envsci.2012.08.001

Hein, L., van Koppen, K., De Groot, R., and van Ierland, E. C. (2006). Spatial scales, stakeholders and the valuation of ecosystem services. Ecol. Econ. 57, 209-228. doi: 10.1016/j.ecolecon.2005.04.005

Hou, Y., Burkhard, B., and Müller, F. (2013). Uncertainties in landscape analysis and ecosystem service assessment. J. Environ. Manag. 127, S117. doi: 10.1016/j.jenvman.2012.12.002

Ingegno, B. L., Ferracini, C., Gallinotti, D., Alma, A., and Tavella, L. (2013). Evaluation of the effectiveness of Dicyphus errans (Wolff) as predator of Tuta absoluta (Meyrick). Biol. Control 67, 246-252. doi: 10.1016/j.biocontrol.2013.08.002

Jauker, F., Diekötter, T., Schwarzbach, F., and Wolters, V. (2009). Pollinator dispersal in an agricultural matrix: opposing responses of wild bees and hoverflies to landscape structure and distance from main habitat. Landscape Ecol. 24, 547-555. doi: 10.1007/s10980-009-9331-2

Jonason, D., Smith, H. G., Bengtsson, J., and Birkhofer, K. (2013). Landscape simplification promotes weed seed predation by carabid beetles (Coleoptera; Carabidae). Landscape Ecol. 28, 478-494. doi: 10.1007/s10980-013-9848-2

Jönsson, A. M., Anderbrant, O., Holmér, J., Johansson, J., Schurgers, G., Svensson, G. P., et al. (2014a). Enhanced science-stakeholder communication to improve ecosystem model performance for climate change impact assessments. Ambio. doi: 10.1007/s13280-014-0553-4. [Epub ahead of print].

Jönsson, A. M., Lagergren, F., and Smith, B. (2014b). Forest management facing climate change - an ecosystem model analysis of adaptation strategies. Mitig. Adapt. Strateg. Glob. Change. doi: 10.1007/s11027-013-9487-6

Jonsson, M., Bommarco, R., Ekbom, B., Smith, H. G., Bengtsson, J., CaballeroLopez, B., et al. (2014). Ecological production functions for biological control services in agricultural landscapes. Method. Ecol. Evol. 5, 243-252. doi: 10.1111/2041-210X.12149

Kandziora, M., Burkhard, B., and Müller, F. (2013). Interactions of ecosystem properties, ecosystem integrity and ecosystem service indicators - A theoretical matrix exercise. Ecol. Indic. 28, 54-78. doi: 10.1016/j.ecolind.2012.09.006

Kennedy, C. M., Lonsdorf, E., Neel, M. C., Williams, N. M., Ricketts, T. H., Winfree, R., et al. (2013). A global quantitative synthesis of local and landscape effects on wild bee pollinators in agroecosystems. Ecol. Lett. 16, 584-599. doi: 10.1111/ele.12082

Kowarik, I. (2011). Novel urban ecosystems, biodiversity, and conservation. Environ. Pollut. 159, 1974-1983. doi: 10.1016/j.envpol.2011.02.022

Kremen, C. (2005). Managing ecosystem services: what do we need to know about their ecology? Ecol. Lett. 8, 468-479. doi: 10.1111/j.1461-0248.2005.00751.x

Kremen, C., Williams, N. M., Aizen, M. A., Gemmill-Herren, B., LeBuhn, G., Minckley, R., et al. (2007). Pollination and other ecosystem services produced by mobile organisms: a conceptual framework for the effects of land-use change. Ecol. Lett. 10, 299-314. doi: 10.1111/j.1461-0248.2007.01018.x

Kremen, C., Williams, N. M., and Thorp, R. W. (2002). Crop pollination from native bees at risk from agricultural intensification. Proc. Natl. Acad. Sci. U.S.A. 99, 16812-16816. doi: 10.1073/pnas.262413599

Krueger, T., Page, T., Hubacek, K., Smith, L., and Hiscock, K. (2012). The role of expert opinion in environmental modelling. Environ. Model. Softw. 36, 4-18. doi: 10.1016/j.envsoft.2012.01.011

Lal, R. (2005). Enhancing crop yields in the developing countries through restoration of the soil organic carbon pool in agricultural lands. Land Degrad. Dev. 17, 197-209. doi: 10.1002/ldr.696

Langellotto, G. A., and Denno, R. F. (2004). Responses of invertebrate natural enemies to complex-structured habitats: a meta-analytical synthesis. Oecologia 139, 1-10. doi: 10.1007/s00442-004-1497-3 
Lautenbach, S., Volk, M., Gruber, B., Dormann, C. F., Strauch, M., and Seppelt, R. (2010). "Quantifying ecosystem service trade-offs," in International Congress on Environmental Modelling and Software Modelling for Environment's Sake, Fifth Biennial Meeting, eds D. A. Swayne, W. Yang, A. A. Voinov, A. Rizzoli, and T. Filatova (Ottawa, ON: International Environmental Modelling and Software Society (iEMSs)).

Legendre, P., and Legendre, L. (2012). Numerical Ecology. Amsterdam, Boston: Elsevier.

Leibold, M. A., Holyoak, M., Mouquet, N., Amarasekare, P., Chase, J. M., Hoopes, M. F., et al. (2004). The metacommunity concept: a framework for multi-scale community ecology. Ecol. Lett. 7, 601-613. doi: 10.1111/j.14610248.2004.00608.x

Letourneau, D. K., Jedlicka, J. A., Bothwell, S. G., and Moreno, C. R. (2009). Effects of natural enemy biodiversity on the suppression of arthropod herbivores in terrestrial ecosystems. Annu. Rev. Ecol. Evol. Syst. 40, 573-592. doi: 10.1146/annurev.ecolsys.110308.120320

Levin, S. A. (1992). The problem of pattern and scale in ecology. Ecology 73, 1943-1967. doi: 10.2307/1941447

Lima, S. L., and Zollner, P. A. (1996). Towards a behavioral ecology of ecological landscapes. Trends Ecol. Evol. 11, 131-135. doi: 10.1016/0169-5347(96)81094-9

Luck, G. W., Chan, K. M., and Klien, C. J. (2012). Identifying spatial priorities for protecting ecosystem services. F1000 Res. 1:17 doi: 10.12688/f1000research. 1-17.v1

Luck, G. W., Daily, G. C., and Ehrlich, P. R. (2003). Population diversity and ecosystem services. Trends Ecol. Evol. 18, 331-336. doi: 10.1016/S0169-5347(03) 00100-9

Lundin, O., Smith, H. G., Rundlöf, M., and Bommarco, R. (2013). When ecosystem services interact: crop pollination benefits depend on the level of pest control. Proc. Biol. Sci. 280:20122243. doi: 10.1098/rspb.2012.2243

Mace, G. M., Norris, K., and Fitter, A. H. (2012). Biodiversity and ecosystem services: a multilayered relationship. Trends Ecol. Evol. 27, 19-26. doi: 10.1016/j.tree.2011.08.006

Maes, J., Paracchini, M. L., and Zulian, G. (2011). A European Assessment of the Provision of Ecosystem Services. Towards an Atlas of Ecosystem Services. Luxembourg: Publications Office.

Martín-López, B., Gómez-Baggethun, E., García-Llorente, M., and Montes, C. (2014). Trade-offs across value-domains in ecosystem services assessment. Ecol. Indic. 37, 220-228. doi: 10.1016/j.ecolind.2013.03.003

Maskell, L. C., Crowe, A., Dunbar, M. J., Emmett, B., Henrys, P., Keith, A. M., et al. (2013). Exploring the ecological constraints to multiple ecosystem service delivery and biodiversity. J. Appl. Ecol. 50, 561-571. doi: 10.1111/1365-2664.12085

Mastrangelo, M. E., Weyland, F., Villarino, S. H., Barral, M. P., Nahuelhual, L., and Lateraa, P. (2014). Concepts and methods for landscape multifunctionality and a unifying framework based on ecosystem services. Landscape Ecol. 29, 345-358. doi: 10.1007/s10980-013-9959-9

McCune, B., Grace, J. B., and Urban, D. L. (2002). Analysis of Ecological Communities. Gleneden Beach, OR: MjM Software Design.

Médiène, S., Valantin-Morison, M., Sarthou, J. P., Tourdonnet, S., Gosme, M., Bertrand, M., et al. (2011). Agroecosystem management and biotic interactions: a review. Agron. Sustain. Dev. 31, 491-514. doi: 10.1007/s13593-011-0009-1

Menalled, F. D., Lee, J. C., and Landis, D. A. (1999). Manipulating carabid beetle abundance alters prey removal rates in corn fields. Biocontrol 43, 441-456. doi: 10.1023/A:1009946004251

Mols, C. M., Visser, M. E., and Jones, P. (2007). Great tits (Parus major) reduce caterpillar damage in commercial apple orchards. PloS ONE 2:e202. doi: 10.1371/journal.pone.0000202

Montoya, J. M., and Raffaelli, D. (2010). Climate change, biotic interactions and ecosystem services. Philos. Trans. R. Soc. B 365, 2013-2018. doi: 10.1098/rstb.2010.0114

Mooney, H., Larigauderie, A., Cesario, M., Elmquist, T., Hoegh-Guldberg, O., Lavorel, S., et al. (2009). Biodiversity, climate change, and ecosystem services. Curr. Opin. Environ. Sustain. 1, 46-54. doi: 10.1016/j.cosust.2009.07.006

Mori, A. S., Furukawa, T., and Sasaki, T. (2013). Response diversity determines the resilience of ecosystems to environmental change. Biol. Rev. 88, 349-364. doi: $10.1111 /$ brv. 12004

Nelson, E., and Daily, G. C. (2010). Modelling ecosystem services in terrestrial systems. F1000 Biol. Rep. 2:53. doi: 10.3410/B2-53

Nelson, E., Mendoza, G., Regetz, J., Polasky, S., Tallis, H., Cameron, D., et al. (2009). Modeling multiple ecosystem services, biodiversity conservation, commodity production, and tradeoffs at landscape scales. Front. Ecol. Environ. 7, 4-11. doi: $10.1890 / 080023$

Nelson, E., Polasky, S., Lewis, D. J., Plantinga, A. J., Lonsdorf, E., White, D., et al. (2008). Efficiency of incentives to jointly increase carbon sequestration and species conservation on a landscape. Proc. Natl. Acad. Sci. U.S.A. 105, 9471-9476. doi: 10.1073/pnas.0706178105

Nicholson, E., Mace, G. M., Armsworth, P. R., Atkinson, G., Buckle, S., Clements, T., et al. (2009). Priority research areas for ecosystem services in a changing world. J. Appl. Ecol. 46, 1139-1144. doi: 10.1111/j.1365-2664.2009. 01716.x

Norgaard, R. B. (2010). Ecosystem services: from eye-opening metaphor to complexity blinder. Ecol. Econ. 69, 1219-1227. doi: 10.1016/j.ecolecon.2009.11.009

Östman, Ö., Ekbom, B., and Bengtsson, J. (2003). Yield increase attributable to aphid predation by ground-living polyphagous natural enemies in spring barley in Sweden. Ecol. Econ. 45, 149-158. doi: 10.1016/S0921-8009(03)00007-7

Polce, C., Termansen, M., Aguirre-Gutiérrez, J., Boatman, N. D., Budge, G. E., Crowe, A., et al. (2013). Species distribution models for crop pollination: a modelling framework applied to Great Britain. PloS ONE 8:e76308. doi: 10.1371/journal.pone.0076308

Power, A. G. (2010). Ecosystem services and agriculture: tradeoffs and synergies. Philos. Trans. Roy. Soc. B 365, 2959-2971. doi: 10.1098/rstb.2010.0143

Quinn, G. P., and Keough, M. J. (2002). Experimental Design and Data Analysis for Biologists. Cambridge, New York: Cambridge University Press. doi: 10.1017/CBO9780511806384

Raffaelli, D., and White, P. C. (2013). Ecosystems and their services in a changing world. Adv. Ecol. Res. 48, 1-70. doi: 10.1016/B978-0-12-417199-2. 00001-X

Raudsepp-Hearne, C., Peterson, G. D., and Bennett, E. M. (2010). Ecosystem service bundles for analyzing tradeoffs in diverse landscapes. Proc. Natl. Acad. Sci. U.S.A. 107, 5242-5247. doi: 10.1073/pnas.0907284107

Reyers, B., Biggs, R., Cumming, G. S., Elmqvist, T., Hejnowicz, A. P., and Polasky, S. (2013). Getting the measure of ecosystem services: a social-ecological approach. Front. Ecol. Environ. 11, 268-273. doi: 10.1890/120144

Ricketts, T. H., Regetz, J., Steffan-Dewenter, I., Cunningham, S. A., Kremen, C., Bogdanski, A., et al. (2008). Landscape effects on crop pollination services: are there general patterns? Ecol. Lett. 11, 499-515. doi: 10.1111/j.14610248.2008.01157.x

Rodríguez, J. P., Beard, T. D. Jr., Bennett, E. M., Cumming, G. S., Cork, S. J., Agard, J., et al. (2006). Trade-offs across space, time, and ecosystem services. Ecol. Soc. $11,28$.

Rusch, A., Valantin-Morison, M., Roger-Estrade, J., and Sarthou, J. P. (2012). Using landscape indicators to predict high pest infestations and successful natural pest control at the regional scale. Landsc. Urban Plan. 105, 62-73. doi: 10.1016/j.landurbplan.2011.11.021

Schmidt, M. H., Lauer, A., Purtauf, T., Thies, C., Schaefer, M., and Tscharntke, T. (2003). Relative importance of predators and parasitoids for cereal aphid control. Proc. Biol. Sci. 270, 1905-1909. doi: 10.1098/rspb.2003.2469

Schröter, D., Cramer, W., Leemans, R., Prentice, I. C., Araújo, M. B., Arnell, N. W., et al. (2005). Ecosystem service supply and vulnerability to global change in Europe. Science 310, 1333-1337. doi: 10.1126/science.1115233

Seppelt, R., Dormann, C. F., Eppink, F. V., Lautenbach, S., and Schmidt, S. (2011). A quantitative review of ecosystem service studies: approaches, shortcomings and the road ahead. J. Appl. Ecol. 48, 630-636. doi: 10.1111/j.13652664.2010.01952.x

Setälä, H., Bardgett, R. D., Birkhofer, K., Brady, M., Byrne, L., De Ruiter, P. C., et al. (2014). Urban and agricultural soils: conflicts and trade-offs in the optimization of ecosystem services. Urban Ecosyst. 17, 239-253. doi: 10.1007/s11252-0130311-6

Shrestha, R. B., and Parajulee, M. N. (2013). Potential cotton aphid, Aphis gossypii, population suppression by arthropod predators in upland cotton. Insect Sci. 20, 778-788. doi: 10.1111/j.1744-7917.2012.01583.x

Siemann, E., Tilman, D., Haarstad, J., and Ritchie, M. (1998). Experimental tests of the dependence of arthropod diversity on plant diversity. Am. Nat. 152, 738-750. doi: 10.1086/286204

Sih, A., and Baltus, M. S. (1987). Patch size, pollinator behavior, and pollinator limitation in catnip. Am. Nat. 68, 1679-1690.

Stallman, H. R. (2011). Ecosystem services in agriculture: determining suitability for provision by collective management. Ecol. Econ. 71, 131-139. doi: 10.1016/j.ecolecon.2011.08.016 
Sterner, T., and Persson, U. M. (2008). An even sterner review - introducing relative prices into the discounting debate. Rev. Environ. Econ. Policy 2, 61-76. doi: 10.1093/reep/rem024

Stuart, D., and Gillon, S. (2013). Scaling up to address new challenges to conservation on US farmland. Land Use Policy 31, 223-236. doi: 10.1016/j.landusepol.2012.07.003

Sutherland, L. A., Gabriel, D., Hathaway-Jenkins, L., Pascual, U., Schmutz, U., Rigby, D., et al. (2012). The 'Neighbourhood Effect': a multidisciplinary assessment of the case for farmer co-ordination in agri-environmental programmes. Land Use Policy 29, 502-512. doi: 10.1016/j.landusepol.2011.09.003

Tallis, H., Kareiva, P., Marvier, M., and Chang, A. (2008). An ecosystem services framework to support both practical conservation and economic development. Proc. Natl. Acad. Sci. U.S.A. 105, 9457-9464. doi: 10.1073/pnas.0705797105

TEEB. (2010). The Economics of Ecosystems and Biodiversity: Mainstreaming the Economics of Nature: A Synthesis of the Approach, Conclusions and Recommendations of TEEB. Malta: Progress Press.

Tilman, D., Cassman, K. G., Matson, P. A., Naylor, R., and Polasky, S. (2002). Agricultural sustainability and intensive production practices. Nature 418, 671-677. doi: 10.1038/nature01014

Tixier, P., Peyrard, N., Aubertot, J. N., Gaba, S., Radoszycki, J., Caron-Lormier, G., et al. (2013). Modelling interaction networks for enhanced ecosystem services in agroecosystems. Adv. Ecol. Res. 49, 437-480. doi: 10.1016/B978-0-12-4200029.00007-X

Tscharntke, T., Klein, A. M., Kruess, A., Steffan-Dewenter, I., and Thies, C. (2005). Landscape perspectives on agricultural intensification and biodiversity - ecosystem service management. Ecol. Lett. 8, 857-874. doi: 10.1111/j.14610248.2005.00782.x

Tscharntke, T., Tylianakis, J. M., Rand, T. A., Didham, R. K., Fahrig, L., Batáry, P., et al. (2012). Landscape moderation of biodiversity patterns and processes eight hypotheses. Biol. Rev. 87, 661-685. doi: 10.1111/j.1469-185X.2011.00216.x

Tylianakis, J. M., Tscharntke, T., and Lewis, O. T. (2007). Habitat modification alters the structure of tropical host-parasitoid food webs. Nature 445, 202-205. doi: 10.1038 /nature05429

Van der Biest, K., D’Hondt, R., Jacobs, S., Landuyt, D., Staes, J., Goethals, P., et al. (2014). EBI: an index for delivery of ecosystem service bundles. Ecol. Indic. 37, 252-265. doi: 10.1016/j.ecolind.2013.04.006
Veres, A., Petit, S., Conord, C., and Lavigne, C. (2013). Does landscape composition affect pest abundance and their control by natural enemies? a review. Agric. Ecosyst. Environ. 166, 110-117. doi: 10.1016/j.agee.2011. 05.027

Vihervaara, P., Rönkä, M., and Walls, M. (2010). Trends in ecosystem service research: early steps and current drivers. Ambio 39, 314-324. doi: 10.1007/s13280-010-0048-x

Westman, W. E. (1977). How much are nature's services worth? Science 197, 960-964. doi: 10.1126/science.197.4307.960

Woodcock, T. S., Pekkola, L. J., Dawson, C., Gadallah, F. L., and Kevan, P. G. (2014). Development of a Pollination Service Measurement (PSM) method using potted plant phytometry. Environ. Monit. Assess. 186, 5041-5057. doi: 10.1007/s10661-014-3758-x

Zhang, W., Ricketts, T. H., Kremen, C., Carney, K., and Swinton, S. M. (2007) Ecosystem services and dis-services to agriculture. Ecol. Econ. 64, 253-260. doi: 10.1016/j.ecolecon.2007.02.024

Conflict of Interest Statement: The authors declare that the research was conducted in the absence of any commercial or financial relationships that could be construed as a potential conflict of interest.

Received: 12 October 2014; accepted: 21 December 2014; published online: 12 January 2015.

Citation: Birkhofer K, Diehl E, Andersson J, Ekroos J, Früh-Müller A, Machnikowski F, Mader VL, Nilsson L, Sasaki K, Rundlöf M, Wolters V and Smith HG (2015) Ecosystem services-current challenges and opportunities for ecological research. Front. Ecol. Evol. 2:87. doi: 10.3389/fevo.2014.00087

This article was submitted to Agroecology and Land Use Systems, a section of the journal Frontiers in Ecology and Evolution.

Copyright (C) 2015 Birkhofer, Diehl, Andersson, Ekroos, Früh-Müller, Machnikowski, Mader, Nilsson, Sasaki, Rundlöf, Wolters and Smith. This is an open-access article distributed under the terms of the Creative Commons Attribution License (CC BY). The use, distribution or reproduction in other forums is permitted, provided the original author(s) or licensor are credited and that the original publication in this journal is cited, in accordance with accepted academic practice. No use, distribution or reproduction is permitted which does not comply with these terms. 